\title{
Earth Fissures Triggered by Groundwater Withdrawal and Coupled by Geological Structures in Jiangsu Province, China
}

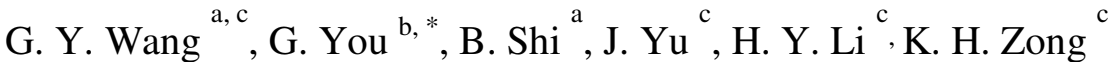

a. Department of Geoscience, Nanjing University, Nanjing 210093, China

b. School of Science and Engineering, University of Ballarat, Ballarat 3353, Australia

c. Geological Survey of Jiangsu Province, Nanjing 210018, China

* Corresponding author: School of Science and Engineering, University of Ballarat, University Drive, Mt Helen, Ballarat, Victoria 3353, Australia. Phone: (61 3) 5327

9141; Fax: (61 3) 5327 9240; Email: g.you@ ballarat.edu.au

\begin{abstract}
Earth fissures in Jiangsu Province, China have caused serious damages to properties, farmlands and infrastructures, and adversely affected the local or regional economic development. Under the geological and environmental background in Jiangsu Province, this paper presents the earth fissures caused by excessive groundwater withdrawal and coupled by distinctive geological structures, such as Ancient Yellow River Fault in Xuzhou karst area, and Ancient Yangtze River Course and bedrock hills in Suzhou, Wuxi and Changzhou area. Although all the earth fissures are triggered by groundwater exploitation, the characteristics are strongly affected by the specific geological and hydrogeological settings. In particular, in the water-thirsty Xuzhou City, the cone of depression caused by groundwater extraction enlarged nearly 20 times and the piezometric head of groundwater declined $17 \mathrm{~m}$ over a decade. As groundwater is extracted from the shallowly buried karst strata in the Ancient Yellow River Fault zone, the development of earth fissures is highly associated with the development of karstic cavities and sinkholes and their distribution is controlled by the Ancient Yellow River Fault with all the 17 sinkholes on the fault. On the other hand, in the rapidly developing Southern Jiangsu Province, groundwater is mainly pumped from the second confined aquifer in the Quaternary, which is distributed neither homogeneously nor isotropically. The second confined aquifer comprises more than $50 \mathrm{~m}$ thick sand over the Ancient Yangtze River Course, but this layer may completely miss on the riverbank and bedrock hills. With a typical drawdown rate of $4 \mathrm{~m}$ to $6 \mathrm{~m}$ per annum, the piezometric head of groundwater in the second confined aquifer has declined $76 \mathrm{~m}$ at Maocunyuan since 1970s and $40 \mathrm{~m}$ at Changjing since mid-1980s, and a large land subsidence, e.g. 1100 $\mathrm{mm}$ at Maocunyuan, is triggered. Coupled with the dramatic change of the bedrock topography that was revealed through traditional geological drilling and modern seismic reflection methods, the geological-structure-controlled differential settlement and earth fissures are phenomenal in this area.
\end{abstract}

Key words: Earth fissure, Groundwater withdrawal, Geological structure, Jiangsu, Land subsidence, Sinkhole 


\section{Introduction}

Earth fissures may also be known as ground cracks or ground fissures in literatures. Earth fissures can be developed due to earthquakes (Prestininzi and Romeo 2000; Sarkar 2004; Yuan et al. 2004), active faults (Liu et al. 1990; Lee et al. 1996; Li et al. 2000), groundwater withdrawal (Holzer and Pampeyan 1981; Schumann et al. 1986; Contaldo and Mueller 1991; Corwin et al. 1991), heavy rainfalls (Kyriiacou 1990; Gao et al. 1997; Ayalew et al. 2004), civil and mining engineering (Beckwith et al. 1991; Li et al. 2004; Qi et al. 2004), etc. As earth fissures may cause damages to properties, infrastructures and environment (Lee et al. 1996; Asfaw 1998; Li et al. 2004; Yuan et al. 2004), there are a number of studies on various fissures about their identification (Beckwith et al. 1991), characterization (Haneberg et al. 1991; Keaton and Shlemon 1991), origin (Lee et al. 1996; Li et al. 2000; Ayalew et al. 2004), process and mechanism of fissure formation (Holzer and Pampeyan 1981; Liu et al. 1990; Lee et al. 1996; Li et al. 2000; Yu et al. 2004), etc. In particular, earth fissures induced by groundwater decline have attracted a wide attention probably because they are caused by human activities, impose great damages in urban area and are a recurrent problem.

Earth fissures, as a kind of geohazard that may cause serious damages, have been reported in China. Earth fissures in Northern China, in particular, have been well studied (Liu et al. 1990; Lee et al. 1996; Li et al. 2000). Seven earth fissure zones were evident in Xian City in 1976 and the causative mechanism was attributed to a creeping fault (Liu et al. 1990). The number of earth fissure zones in Xian was increased to 10 and the causative mechanism was concluded as land subsidence and rejuvenation of faults resulted from the excessive groundwater withdrawal (Lee et al. 1996). The origin of earth fissures in five places in Shanxi Graben System, including Xian, was reported as fault-related, grounder withdrawal and silty loess collapse (Li et al. 2000). Earth fissures related to civil and mining engineering have also been investigated in China ( $\mathrm{Li}$ et al. 2004; Qi et al. 2004). Qi et al. (2004) investigated the formation and distribution of deep cracks in a slope area and found that the causative mechanism was the combination of tectonic process and succeeding unloading process. Li et al. (2004) reported an evident ground movement and 37 ground fissures at the No.2 Mine, Jinchuan Nickel Mine, and identified the causative factors as the redistribution of insitu stresses, the low stiffness of the backfill and the influence of mining sequence and rate.

Although earth fissure is a special type of geohazard that are associated with many other geohazards, researches on its causative mechanism, development and distribution are significant in a particular region to predict geohazards and to reduce potential damages. A recent study of using ground loss theory to predict the earth fissuring and faulting caused by regional groundwater decline (Rojas et al. 2002), may be an indication of the diversities of demands for researches on earth fissures. A number of types of geohazards are observed in Jiangsu Province with different characterizations. Some geohazards may regionally occur in-group under the specific geological environment, for example, landslides mainly occur in Yuntai and Ningzhen Mountains. Some geohazards, such as land subsidence in Suxichang - Chinese abbreviation of Suzhou, Wuxi and Changzhou area, may progressively take place. Some geohazards like earth fissures may suddenly 
occur. The others, such as earthquake, may periodically and randomly happen. From our experiences working on geohazards, this paper presents the geological background and several cases of earth fissures triggered by groundwater withdrawal and coupled by the influence of special geological structures, such as Ancient Yellow River Fault, Ancient Yangtze River Course and bedrock hills, in Jiangsu Province, China. The geological structures were explored by either the traditional drilling or a modern geophysical method, in particular a shallow seismic wave technique, or a combination of them.

\section{Geological and Environmental Background}

Jiangsu Province is located in the coastal area of Eastern China with a land area of about $100000 \mathrm{~km}^{2}, 95 \%$ of which is low plains, and the rest is mountains. Geologically, Jiangsu can be structurally divided into three plates, namely Yangtze Plate, Huabei Plate and Su-Lu Plate as shown in Fig. 1. Each of the plates has different geological settings. Pre-Quaternary strata, from Archaean Group to Neogene of Cenozoic Group, are distributed with spatial variations of different rock types. Quaternary strata, from Pleistocene to Holocene, are extensively presented as expansive clay, stiff clay, soft clay, silty clay and sandy soil, with a varying degree of consolidation from under-consolidated to over-consolidated.

There are several large surface water bodies in Jiangsu Province, such as Yellow Sea and East Sea to its eastern border, Yangtze River passing through the south into East Sea and Taihu Lake on its southern border. But groundwater is an important resource of water supply for living, agriculture and industry across the province due to high density of population and rapid development of economy. There are several aquifers for groundwater extraction, and most is from the confined porous granular soil layer, second by from the fractured karst stratum.

Earth fissures and land subsidence may occur under a variety of causative mechanisms in Jiangsu Province, for examples, excessive groundwater withdrawal in Suxichang (Zhu et al. 1993; Wang 1998; Chen et al. 2003; Zhang et al. 2007), cavities and sinkholes in the shallowly buried karst in Xuzhou City, underground mining in Xuzhou, Nanjing (Wang et al. 2008) and Lianyungang and quarrying and other engineering activities in the mountain area.

Earth fissures occurred in 119 zones with more than 600 fissures of a total length more than $80 \mathrm{~km}$, involved in 36 counties in the province. 90 of the fissure zones with more than 350 fissures are a structural genesis, and 29 zones with more than 150 fissures are nonstructural (Gao et al. 1997). Earth fissure occurrences in Jiangsu Province come to a climax since 1989. For examples, earth fissures occur in succession in Suxichang area; landslides, debris/earth flows, land subsidence and earth fissures happened a few hundred times in Yuntai and Ningzhen Mountains after the one-in-100-years rain in 1991 (Gao et al. 1997); earth fissures and house damages in Dongting County, Wuxi City, forced the terrified villagers to leave their houses since 1990 (Zhu et al. 1993). From 1994 to 1998, earth fissures occurred five times in the western area of Wuxi City (Hu and Wu 1998). 
Earth fissures occur in both urban and rural areas in Jiangsu. The earth fissures in urban and developed areas can cause more serious damages than in rural and developing areas. Firstly, because of the high density of population and buildings, and the sophisticated networks of various infrastructures in urban area, the vulnerability of urban ecosystems is conceivable. Secondly, the economic output per unit area in a developed area is far more than that in a developing area

\section{Xuzhou City earth fissures in karst ground controlled by Ancient Yellow River Fault}

In Jiangsu Province, earth fissures related to the karst land subsidence occur mainly in Xuzhou and occasionally in Nanjing and Wuxi. In Xuzhou, the karst is located at a strongly water-bearing stratum in an Ancient Yellow River Fault zone, and it is overlain by thin Quaternary loose soils. Xuzhou is a heavily populated industrial city in northwest of Jiangsu Province and depends on groundwater. Extracting groundwater from the karst stratum was started in 1945, and the groundwater drawdown was $11.5 \mathrm{~m}$ from 1945 to 1976 as the pumping rate was relatively low. The groundwater-pumping wells have rapidly increased since 1976, so the quantity of groundwater withdrawn has steadily risen. As a result, the groundwater has progressively declined, and formed a regional cone of depression. In 1980, the depression was about $3.5 \mathrm{~km}^{2}$, and the margin of groundwater head in the cone of depression was $17.6 \mathrm{~m}$. In 1985, the depression expanded to $39.5 \mathrm{~km}^{2}$, and the difference of piezometric head in the cone was $3.65 \mathrm{~m}$. In 1989, the depression reached to $66.8 \mathrm{~km}^{2}$, and the margin of piezometric head was $0.68 \mathrm{~m}$.

Earth fissures and sinkholes are formed in association with the rapid depletion of groundwater in Xuzhou urban area. Shown in Fig. 2 is the distribution of the earth fissures and sinkholes in Xuzhou since May 1986. These surface collapses caused enormous economic loss as the consequences of damages to infrastructures and buildings. Their main nature of Xuzhou karst earth fissures can be summarized as follows:

- Land subsidence and earth fissures are entirely located in the depression zone. When the groundwater table fluctuates, karstic cavities are formed in the limestone stratum along an ancient river course. Year after year, the karstic sinkhole occurs in the shallow topsoils, resulting in earth fissures surrounding the sinkhole;

- The majority of land subsidence and earth fissures are in sandy soil layers on the ancient river course; the minority is distributed in sandy-clayey soil layers;

- The Ancient Yellow River Fault controls the distribution of land subsidence and earth fissures, and the 17 sinkholes are entirely scattered on the fault. Due to the intensively developed karst in Cambrian and Ordovician limestone in the fault zone, the fault is functioned as a strong drainage of the karstic groundwater.

There are a number of literatures on karstic sinkholes, for example, studies on the mechanism and development (Hyatt and Jacobs 1996; Li and Zhou 1999; Lolcama et al. 2002; Salvati and Sasowsky 2002; Billi et al. 2007; Eeckhaut et al. 2007), remediation 
and prevention ( $\mathrm{Li}$ and Zhou 1999; Lolcama et al. 2002; Eeckhaut et al. 2007), and prediction through modeling (Goodings and Abdulla 2002), which can be referred by readers for more details in a particular concern.

\section{Earth Fissures affected by the Ancient Yangtze River Course}

Suxichang area is of the most serious land subsidence caused by groundwater withdrawal in Jiangsu Province. For examples, the maximum land subsidence reached $1800 \mathrm{~mm}$ in Changzhou City (Zhang et al. 2007), nearly $1200 \mathrm{~mm}$ in Suzhou City from 1983 to 1997 (Chen et al. 2003), and $110 \mathrm{~mm}$ in northern Wuxi City from 1982 to 1986 . The land subsidence related earth fissures are mainly scattered in the west of Wuxi City, Jiangyin County and Wujin County. Fig. 3 is the distribution of earth fissure zones in Wuxi City and Jiangyin County. As shown in Fig. 3, the earth fissures on the strip from Dongting to Changjing are typically trending at NNE, so are the earth fissures at Henglin, but the earth fissures at Shitangwan trends nearly EW.

The Quaternary soils in Suxichang area ranges from $70 \mathrm{~m}$ to $120 \mathrm{~m}$ thick, and an Ancient Yangtze River Course is underlain in the northwest direction passing through Changzhou, Shitangwan and Wuxi City into Dongting (refer to Fig. 1 and Fig. 3), which comprises the second confined aquifer system in the region. The stratum configuration of the Quaternary experiences a sharp alteration that aquifer and aquitard are in contact with the steep bedrock of the ancient riverbank. As a result of the excessive groundwater pumping, the groundwater drawdown is more than $30 \mathrm{~m}$ in the region since 1964 . Under the same piezometric head drawdown, the consolidation of soil layers is significantly different on two sides of the steep contact due to the alteration of stratum properties, resulting in differential land subsidence and earth fissures. Maocunyuan and Shitangwan earth fissures depicted below are two cases of this type of fissures originated from groundwater withdrawal from the Ancient Yangtze River Course and developed under the control of this particular geological structure.

\subsection{Maocunyuan earth fissures}

As groundwater pumping from the second confined aquifer, the main pumping aquifer in the region, becomes progressively intensive since 1970s, the piezometric head of groundwater has declined from $-10 \mathrm{~m}$ to current $-86 \mathrm{~m}$ in the aquifer and the cumulative land subsidence has reached $1100 \mathrm{~mm}$. But the excessive groundwater pumping continues, so geohazards from the earth fissures are worsened, in particular at Maocunyuan. The earth fissures at Maocunyuan trends at NEE as shown in Fig. 4. The earth fissure zone is about $1000 \mathrm{~m}$ long and more than $100 \mathrm{~m}$ wide. The opening of a single fissure is $30 \mathrm{~mm}$ to $150 \mathrm{~mm}$ with a visible depth $100 \mathrm{~mm}$ to $1260 \mathrm{~mm}$. The fissures damaged some houses. At the beginning of 1996, the earth fissure zone gradually increased in length and width with a substantial differential land subsidence, for instance, the differential subsidence at a fissure reached $380 \mathrm{~mm}$ with the northern part of the fissure faulting downwards. At present, the earth fissures are continuously developing. 
Geological drilling found an Ancient Yangtze River Course underlying the northern side of the earth fissures. From the soil profile in Fig 5, the top five layers comprise silty clay and clay alternately, with some discontinuous sand seams in the second silty clay layer from surface downward. But the soil profile exhibits a great irregularity further downward. A $50 \mathrm{~m}$ thick sand layer underlain by a clay layer and bedrock consists the second confined aquifer on the north side, while the sand layer misses on the south. In addition, the bedrock slope on the left end of the sand layer is steep and a fault is underlain.

Correlative analyses discover that the trending direction of the earth fissures is in agreement with the longitudinal axis of the Ancient Yangtze River Course, and that the larger land subsidence and the sliding part of the soil are located on the ancient river course. As the thick sand layer in the river course has subjected to a $76 \mathrm{~m}$ drawdown of groundwater since 1970s, this layer would experience significant compaction from the increase of effective stress. In contrast, this layer is missed on the south side. As a result, substantial differential settlement develops, resulting in earth fissures over the Ancient Yangtze River Course.

\subsection{Shitangwan Town Earth Fissures}

Shitangwan Town is 10 kilometers from Wuxi City; refer to Fig. 3. Currently, there are 33 wells in Shitangwan Town with a total groundwater pumping rate of 20000000 $\mathrm{m}^{3} /$ year. As a result, the drawdown rate of groundwater is 5-6 m per annum, and the piezometric head has lowered to $-50 \mathrm{~m}$. Excessive groundwater pumping has not only resulted in the compaction of aquifer and the consolidation of aquitard, but also lead to the land subsidence and earth fissures in the structurally controlled zones.

In May 1991, the ground cracked at Xicai-Qinxiang of Shitangwan Town. From that time on, earth fissures developed, increasing in scale and quantity and opening from a few to up to $25 \mathrm{~mm}$. Meanwhile, the differential land subsidence increased gradually. By the middle of April 1994, an earth fissure zone was formed of $1000 \mathrm{~m}$ long and $60 \mathrm{~m}$ wide. The zone comprised several single fissures, which trended NEE and lined up like a wild goose flying. Most of the fissures were in farmlands, and the middle part traversed a village. The opening of a single fissure was widened to $30 \mathrm{~mm}$ to $80 \mathrm{~mm}$; the visible depth was $200 \mathrm{~mm}$ to $400 \mathrm{~mm}$. The earth fissures caused a number of houses and infrastructures damaged, and a river gateway lost its flood discharge capacity.

From the borehole logging data, the Ancient Yangtze River Course presents on the north of the earth fissures. On the other hand, a bedrock hill is underlain on the south of the earth fissures; the bedrock hill is $116 \mathrm{~m}$ deep from the ground surface, overlain by a thinner aquifer layer. The topography underneath the Quaternary of the fissure zone is similar to that of Maocunyun earth fissures, refer to Fig. 5. Due to the variation of thickness of the water bearing sand layer, the differential land subsidence and earth fissures occur consequently.

In summary, the earth fissures at Maocunyuan and Shitangwan are originated and 
developed under the coupled effects of the excessive groundwater withdrawal from the second confined aquifer, or the Ancient Yangtze River Course in this area, and the resultant geological setting of the ancient river course.

\section{Earth fissures affected by bedrock hills}

In addition to the controlling effect of the Ancient Yangtze River Course on the development and distribution of earth fissures triggered by groundwater withdrawal at Maocuyuan and Shitangwan presented in Section 4, bedrock hills underlying the Quaternary are another geological structure that may have a similar effect on the earth fissures as observed in earth fissure zones at Changjing Town below.

The groundwater pumping started in mid-1980s in Changjing Town, and the piezometric head of groundwater in the second confined aquifer was at $-20 \mathrm{~m}$ with a slow drawdown. In the mid-1990s, the groundwater extraction increased sharply with the rapid development of the local industry. The drawdown rate of the second confined aquifer was $4 \mathrm{~m}$ to $6 \mathrm{~m}$ per year, and the piezometric head was - $55 \mathrm{~m}$ in 1995. The cone of depression in the second confined aquifer enlarged and deepened, and formed a regional cone of depression. Since 1996, groundwater management has been stringently enforced; the piezometric head of the second confined aquifer stays at around - $60 \mathrm{~m}$ level. A maximum land subsidence of $155 \mathrm{~mm}$, however, was observed at Liyuan Printing and Dyeing Factory during the period from June 1999 to June 2000.

\subsection{Hetang Earth Fissures}

In 1995, an earth fissure zone, trending at NE20 ${ }^{\circ}$ and $500 \mathrm{~m}$ long, occurred at Hetang, Changjing Town, Jiangyin County. The earth fissures zone comprises one main fissure and three single tensile fissures as shown in Fig. 6. The northwest side of the fissures is faulting down $20 \mathrm{~m}$ to $30 \mathrm{~m}$. The width of the fissures is $50 \mathrm{~mm}$ to $150 \mathrm{~mm}$. An exploration trench was dug crosscut the main fissure, and the soil layers are found sheared $10-15 \mathrm{~cm}$ at the cross section exposed. The earth fissure zone damaged a variety of buildings and houses along the fissure zone, including a kindergarten, a cloth factory, a tax office, and a community.

Geophysical methods are widely incorporated into geological exploration programs. In particular, seismic techniques take fabulous advantages in bedrock mapping as applied in some large civil projects in Australia (Whiteley 2005; Whiteley 2006). To investigate the causative mechanism of the earth fissures at Hetang, a shallow seismic survey was conducted along three lines - Legend 2 in Fig. 6. The p-wave velocity at different strata in Fig. 7 indicates that there is a NE-trending, long-tongued, ancient topographic bedrock hill underlying the Quaternary in the east of the fissures. The hill is $90-180 \mathrm{~m}$ wide and more than $1000 \mathrm{~m}$ long; its ridge is $60-100 \mathrm{~m}$ deep. A steep slope is in the west of the hill. As the transition zone is on the steep slope, the differential land subsidence within this narrow strip is extraordinary, causing earth fissures and a large number of houses and roads damaged. 


\subsection{Changjing Township Earth Fissures}

Changjing Township earth fissures occurred in 1997, trending NE10 ${ }^{\circ}$ to $30^{\circ}$. The length of a single fissure ranges from $5 \mathrm{~m}$ to $80 \mathrm{~m}$, width of $60 \mathrm{~mm}$ to $100 \mathrm{~mm}$. The fissures in the zone are clustered and paralleled to each other. The length of the earth fissure zone is $1000 \mathrm{~m}$. Both sides of the earth fissure zone, in particular the western side, subsides, indicating the tensile nature. During the period from 9 May to 20 September 2000, the maximum differential settlement reached $34 \mathrm{~mm}$ within one kilometer. The earth fissures damaged 387 houses and buildings, a $9602.8 \mathrm{~m}^{2}$ workshop, two bridges, and several sections of roads and underground pipelines.

A shallow seismic reflection indicated that there is a bedrock hill underlying the earth fissure zone as shown in Fig. 8. The hill trends at $\mathrm{NE} 10^{\circ}$ in accordance with earth fissures zone both directionally and spatially. The depth of hill ridge is $76 \mathrm{~m}$, in contrast to the depth of $163 \mathrm{~m}$ on its northern toe. The slope angle of both hillsides varies between $13^{\circ}$ and $21^{\circ}$.

A geological drilling was conducted to examine the bedrock hill. Two drillholes, as denoted as CK1 and CK2 in Fig. 8 at a spacing of $490 \mathrm{~m}$, penetrated $104.62 \mathrm{~m}$ and $152.00 \mathrm{~m}$ into the bedrock and confirmed the existence of the bedrock hill. As shown in Fig. 9, the Quaternary soil profile is normal above - $80 \mathrm{~m}$. But below $-80 \mathrm{~m}$, on the west of the hill, a $40 \mathrm{~m}$ thick layer of medium to coarse sand, namely the second confined aquifer, underlies a sandy clay; on the east of the hill, a much thinner layer of fine to medium sand, about $15 \mathrm{~m}$ thick on average, overlies the sandy clay. The apparent variation of the soil profile on two sides of the hill contributes to the development of differential land subsidence and earth fissures along the bedrock hill.

\section{Conclusion}

The earth fissure is a deformation of soil and/or rock on the Earth's surface. While the stress acting on the soil and/or rock exceeds its strength, a shear and/or tension crack develops, so its continuum and integrity is broken. Earth fissures may have different origins and causative mechanisms, and they may be controlled by geological, hydrological, gromorphological anomalies (Ayalew et al. 2004) and affected by human being activities (Corwin et al. 1991; Lee et al. 1996; Li et al. 2004). This paper presents the earth fissures caused by excessive groundwater withdrawal and coupled by distinctive geological structures in Jiangsu Province, China, which include the earth fissures in Xuzhou karst area in the Ancient Yellow River Fault zone and those in Suxichang area underlain by the Ancient Yangtze River Course and bedrock hills. Although all the earth fissures are triggered by groundwater exploitation in urban or township areas, the characteristics are diversified by regional geological and hydrogeological settings.

In particular, in the water-thirsty Xuzhou City, the cone of depression caused by groundwater extraction from the fractured karst stratum enlarged nearly 20 times from 
1980 to 1989 , and the piezometric head declined $17 \mathrm{~m}$. As groundwater is extracted from the shallowly buried karst strata in the Ancient Yellow River Fault zone, the development of earth fissures is highly associated with the development of karstic cavities and sinkholes in the limestone stratum and their distribution is controlled by the Ancient Yellow River Fault with all the 17 sinkholes on the fault.

On the other hand, in the infamous groundwater related land subsidence in Suxichang area, groundwater is mainly pumped from the second confined aquifer in the Quaternary (Chen et al. 2003). From the viewpoint of geological structure, the second confined aquifer is distributed neither homogeneously nor isotropically due to the effect of ancient topography underlain the Quaternary. In case of a steep contact of the Quaternary with the bedrock, such as ancient river course and bedrock hill, there is a dramatic change in the Quaternary soil profile. The second confined aquifer layer comprises more than $50 \mathrm{~m}$ thick sand over the Ancient Yangtze River Course presented in the area, but this layer may completely miss on the riverbank, for example at Maocunyuan. The similar soil stratum alteration can be caused by the bedrock hill as evidenced in the Changjing cases. With a typical drawdown rate of $4 \mathrm{~m}$ to $6 \mathrm{~m}$ per annum, the piezometric head in the second confined aquifer has declined $76 \mathrm{~m}$ at Maocuyuan since $1970 \mathrm{~s}$ and $40 \mathrm{~m}$ at Changjing since mid-1980s, and a large land subsidence, for instance $1100 \mathrm{~mm}$ at Maocunyuan, is triggered. Coupled with the dramatic change of the bedrock topography underlying the Quaternary, the geological-structure-controlled differential settlement and earth fissures are developed. In particular, the earth fissures at Maocunyuan and Shitangwan are controlled by the Ancient Yangtze River Course, and the earth fissures at Changjing are influenced by the bedrock hill.

\section{References}

Asfaw, LM (1998) Environmental hazard from fissures in the Main Ethiopian Rift. Journal of African Earth Sciences 27(3/4): 481-490

Ayalew, L, Yamagishi, H and Reik, G (2004) Ground cracks in Ethiopian Rift Valley: facts and uncertainties. Engineering Geology 75: 309-324

Beckwith, GH, Slemmons, DB and Weeks, RE (1991) Use of low-sun angle photography for identification of subsidence-induced earth fissures. Proc. 4th International Conference on Land Subsidence, Houston, IAHS Press: Wallingford,

Billi, A, Valle, A, Brilli, M, Faccenna, C and Funiciello, R (2007) Fracture-controlled fluid circulation and dissolutional weathering in sinkhole-prone carbonate rock from central Italy. Journal of Structural Geology 29: 385-395

Chen, CX, Pei, SP and Jiao, JJ (2003) Land subsidence caused by groundwater exploitation in Suzhou City, China. Hydrogeology Journal 11: 275-287

Contaldo, GJ and Mueller, JE (1991) Earth fissures and land subsidence of the Mimbres 
Basin, Southwestern New Mexico, U.S.A. Proc. 4th International Conference on Land Subsidence, Houston, IAHS Press: Wallingford, 12-17 May 1991

Corwin, EJ, Alhadeff, SC, Oggel, SP and Shlemon, RJ (1991) Earth fissures, urbanization and litigation: a case study from the Temecula, Southwestern Riverside County, California. Proc. 4th International Conference on Land Subsidence, Houston, IAHS Press: Wallingford, 12-17 May 1991

Eeckhaut, MVD, Poesen, J, Dusar, M, Martens, V and Duchateau, P (2007) Sinkhole formation above underground limestone quarries: A case study in South Limburg (Belgium). Geomorphology 91: 19-37

Gao, Z, Zhu, Q, Ji, Y and Chen, X (1997) The research on the distribution feature, genetic type and countermeasure about ground fissure events. Chinese Journal of Seismology(1): 1-10

Goodings, DJ and Abdulla, WA (2002) Stability charts for predicting sinkholes in weakly cemented sand over karst limestone. Engineering Geology 65: 179-184

Haneberg, WC, Reynolds, CB and Reynolds, IB (1991) Geophysical characterization of soil deformation associated with earth fissures near San Marcial Deming, New Mexico. Proc. 4th International Conference on Land Subsidence, Houston, IAHS Press: Wallingford, 12-17 May 1991

Holzer, TL and Pampeyan, EH (1981) Earth fissures and localized subsidence. Water Resources Research 17(1): 223-227

$\mathrm{Hu}$, JP and $\mathrm{Wu}, \mathrm{SL}$ (1998) Geohydrologic environment issues in Suzhou-Changzhou-Wuxi urban group. Chinese Journal of Hydrogeology and Engineering Geology(4): 5-7

Hyatt, JA and Jacobs, PM (1996) Distribution and morphology of sinkholes triggered by flooding following Tropical Storm Alberto at Albany, Georgia, USA. Geomorphology 17: 1996

Keaton, JR and Shlemon, RJ (1991) Fort Hancock earth fissure system, Hudspeth County, Texas: uncertainties and implications. Proc. 4th International Conference on Land Subsidence, Houston, IAHS Press: Wallingford,

Kyriiacou, E (1990) Ground cracks in Aradhippouvillage in Cyprus. Proc. 6th International Congress International Association of Engineering Geology, Amsterdam, Rotterdam: A A Balkema, 6-10 August 1990

Lee, CF, Zhang, JM and Zhang, YX (1996) Evolution and origin of the ground fissures in Xian, China. Engineering Geology 43: 45-55 
Li, GY and Zhou, WF (1999) Sinkholes in karst mining areas in China and some mthods of prevention. Engineering Geology 52: 45-50

Li, X, Wang, SJ, Liu, TY and Ma, FS (2004) Engineering geology, ground surface movement and fissures induced by underground mining in the Jinchuan Nickel Mine. Engineering geology 76: 93- 107

Li, Y, Yang, J and Hu, X (2000) Origin of ground fissures in the Shanxi Graben System, Northern China. Engineering Geology 55: 267-275

Liu, Y, Chen, Z and Zhao, Z (1990) Engineering geological characters of Xian ground fissures and the disaster analyses. Proc. 6th International Congress International Association of Engineering Geology, Amsterdam, Rotterdam: A A Balkema, 6-10 August 1990

Lolcama, JL, Cohen, HA and Tonkin, MJ (2002) Deep karst conduits, flooding, and sinkholes: lessons for aggregates industry. Engineering Geology 65: 1551-157

Prestininzi, A and Romeo, R (2000) Earthquake-induced ground failures in Italy. Engineering Geology 58: 387-397

Qi, S, Wu, F, Yan, F and Lan, H (2004) Mechanism of deep cracks in the left bank slope of Jinping first stage hydropower station. Engineering Geology 73: 129-144

Rojas, E, Arzate, J and Arroyo, M (2002) A method to predict the group fissuring and faulting caused by regional groundwater decline. Engineering Geology 65: 245-260

Salvati, R and Sasowsky, ID (2002) Development of collapse sinkholes in areas of groundwater discharge. Journal of Hydrology 264: 1-11

Sarkar, I (2004) The role of the 1999 Chamoli earthquake in the formation of ground cracks. Journal of Asian Earth Sciences 22: 529-538

Schumann, HH, Cripe, LS and Laney, RL (1986) Land subsidence and earth fissures caused by groundwater depletion in southern Arizona, U.S.A. Proc. 3rd Internation Symposium on Land Subsidence, Venice, IAHS Press: Wallingford, 19-25 March 1986

Wang, GY, You, G, Shi, B and Xu, YL (2008) Investigation on the Nanjing Gypsum Mine Flooding. Proc. of The 2nd International Conference on Geotechnical Engineering for Disaster Mitigation and Rehabilitation, Nanjing, China, 30 May - 2 June 2008

Wang, Z (1998) Sustainable development suffering overexploitation of groundwater Land subsidence and its conflicting in Suzhou-Wuxi-Changzhou area, Jiangsu Province. The Chinese Journal of Geological Hazard and Control 9(2): 18-26

Whiteley, RJ (2005) Gravity mapping and seismic imaging of large tunnel routes in 
Sydney Australia. In: Butler, DK (ed) Near Surface Geophysics. Tulsa, Society of Exploration Geophysics: 503-512

Whiteley, RJ (2006) Seismic imaging of unstable ground. Proc. ASCE 2006, Melbourne, 2-6 July 2006

Yu, J, Wang, XM, Su, XS and Yu, Q (2004) The mechanism analysis on ground fissure disaster formation in Suzhou-Wuxi-Changzhou area. Journal of Jilin University (Earth Science Edition) 34(2): 236-241

Yuan, H, Yang, SH, Andrus, RD and Jung, CH (2004) Liquefaction-induced ground failure: a study of the Chi-Chi earthquake cases. Engineering Geology 71(1-2): 141-155

Zhang, Y, Xue, YQ, Wu, JC, Ye, SJ, Wei, ZX, Li, QF and Yu, J (2007) Characteristics of aquifer system deformation in the Southern Yangtze Delta, China. Engineering Geology 90: $160-173$

Zhang, Y, Xue, YQ, Wu, JC, Yu, J, Wei, ZX and Li, QF (2007) Land subsidence and earth fissures due to groundwater withdrawal in the Southern Yangtze Delta, China. Environmental geology DOI 10.1007/s00254-007-1028-8

Zhu, Q, Gao, Z and Guo, J (1993) Earth fissures and their genesis analysis in Dongting, Wuxi. Chinese Journal of Seismology(3): 31-35 


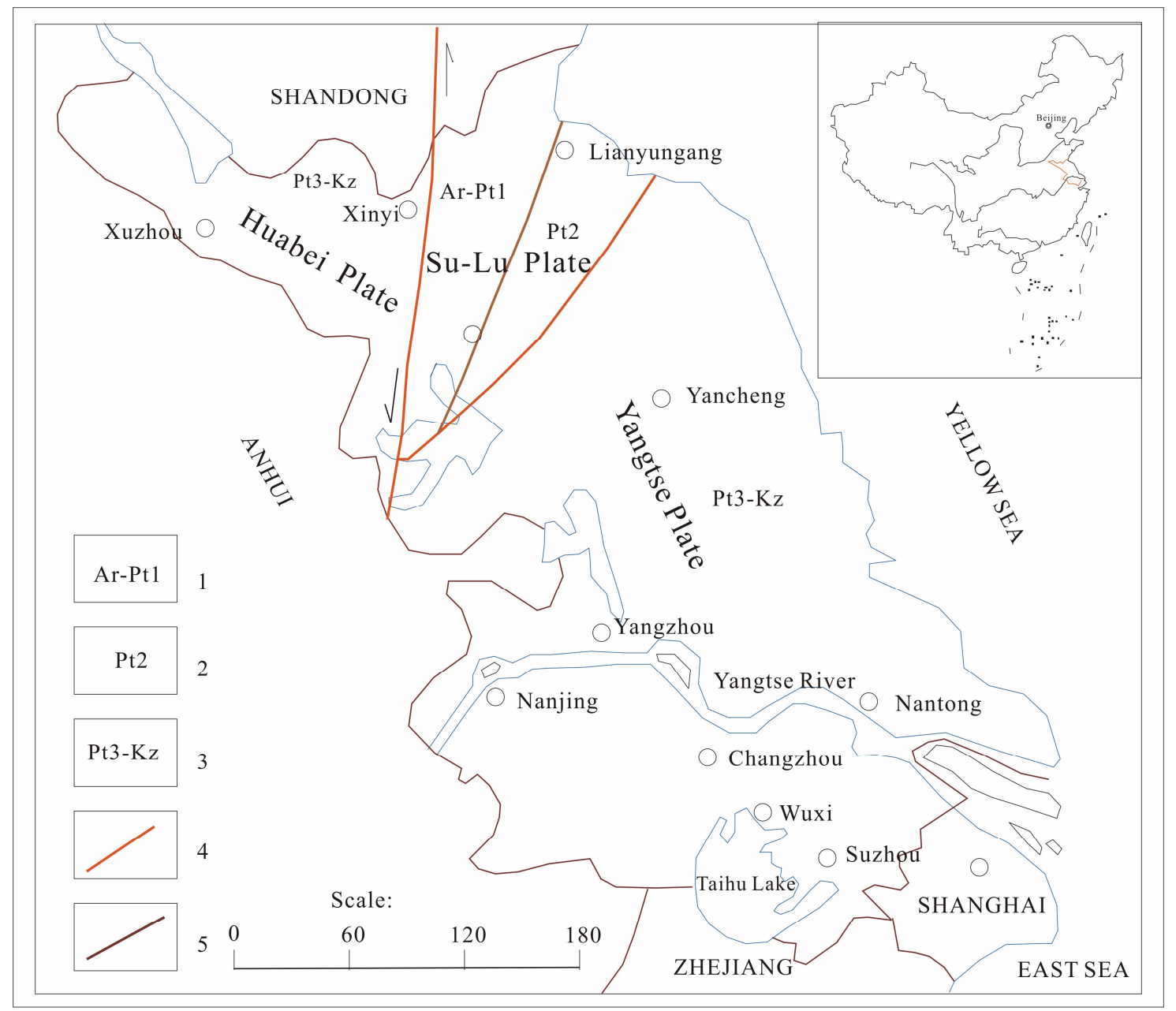

1, Archaean-Old Proterozoic; 2, Middle Proterozoic;

3, New Proterozoic-Cenozoic; 4, Plate Boundary Fault; 5, Fault.

Fig. 1 Geological sketch map of Jiangsu Province, China 


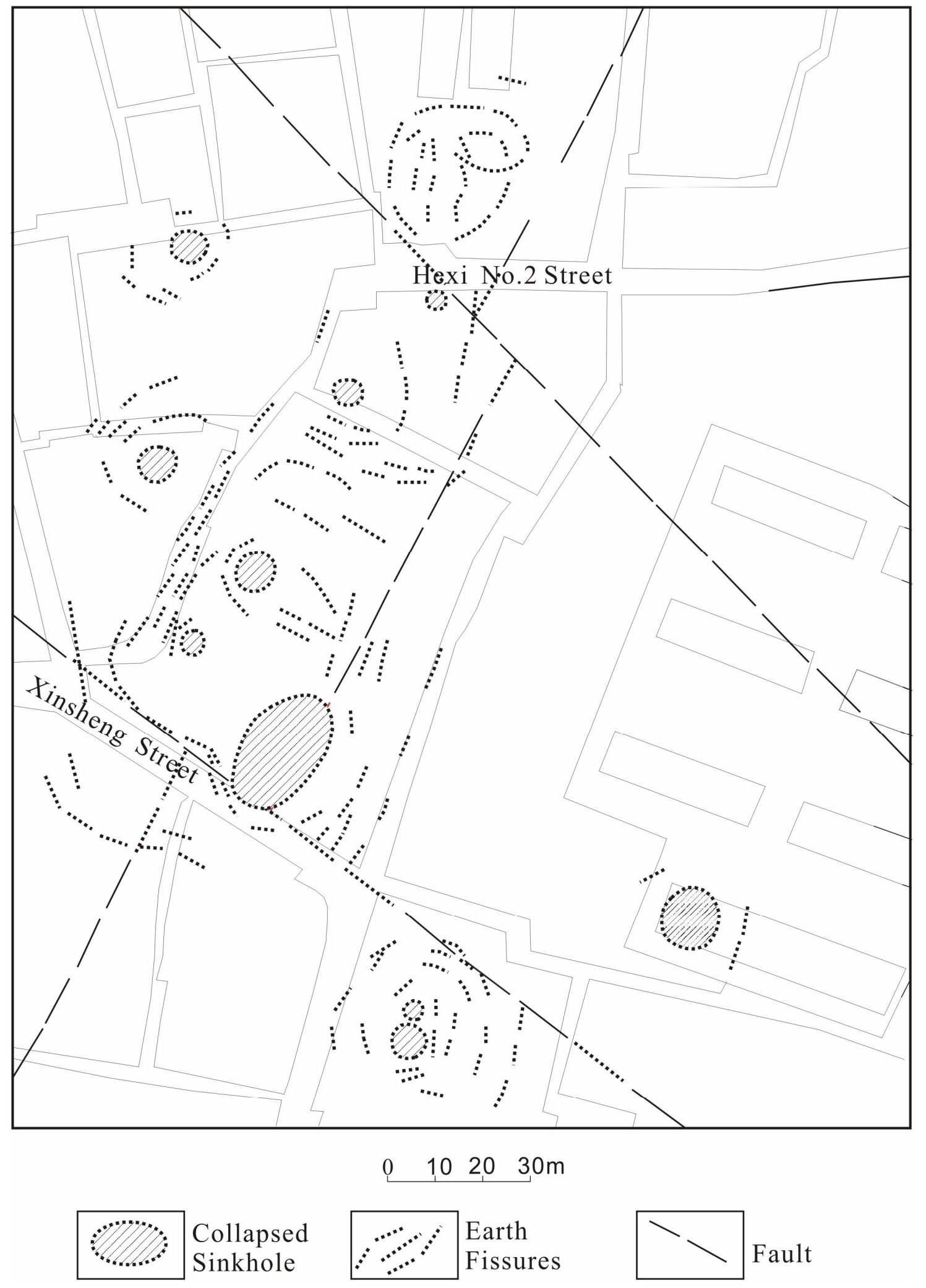

Fig.2 Karst sinkholes and earth fissures in Xuzhou City 


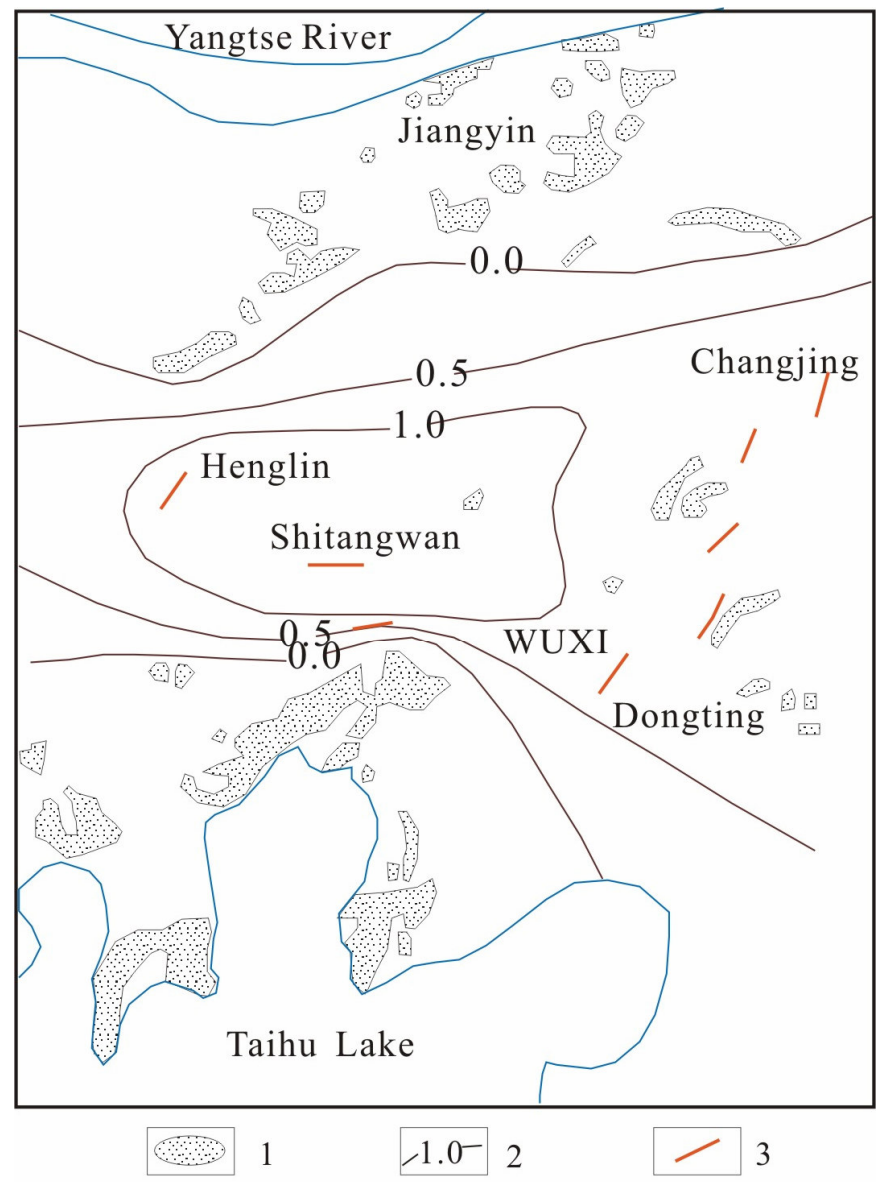

1, Bedrock hill; 2, Isoline of land subsidence;

3, Earth Fissures Zone

Fig. 3 Distribution of earth fissure zones in Jiangin County and Wuxi City 


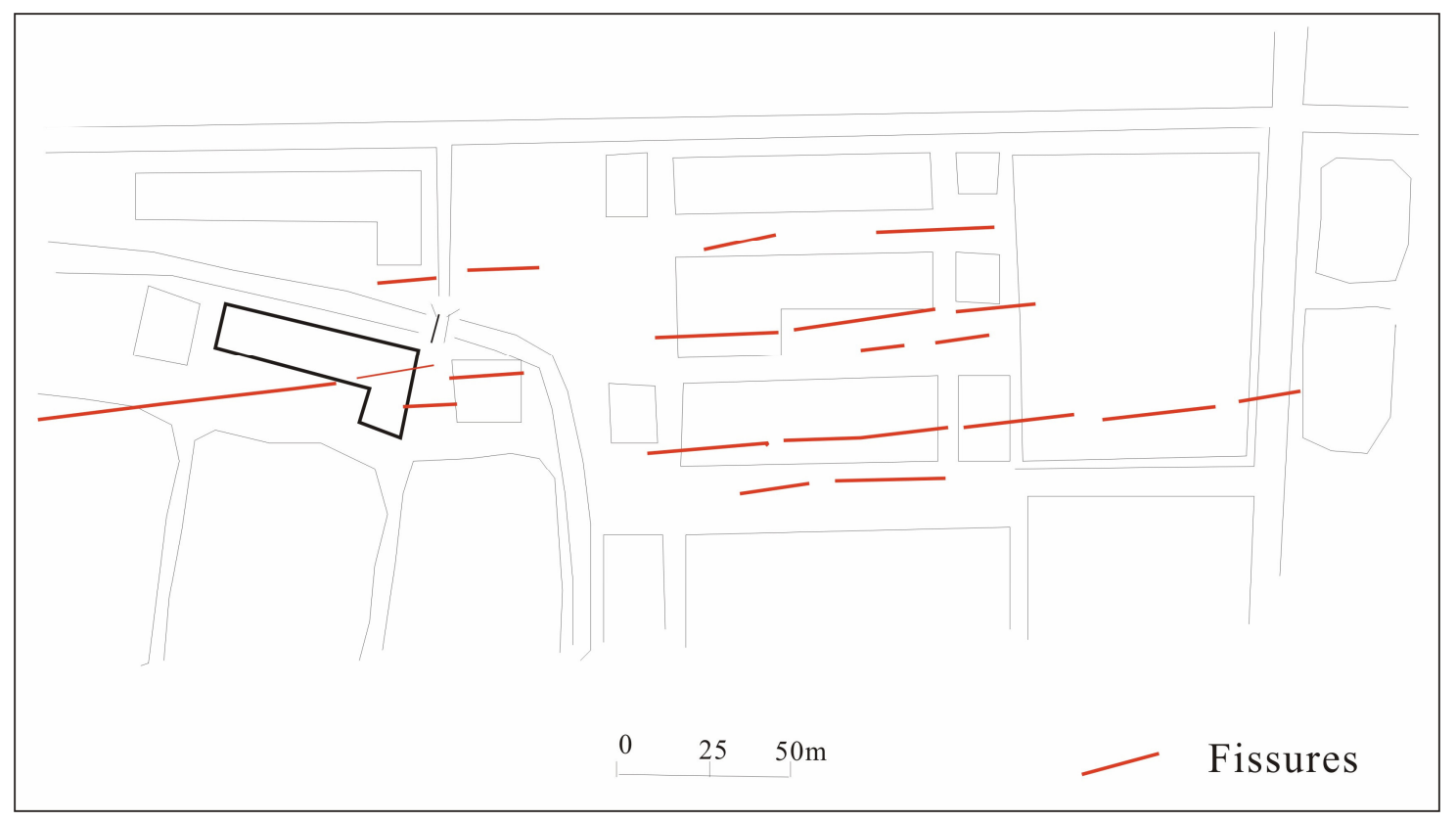

Fig. 4 Distribution of earth fissures at Maocunyuan

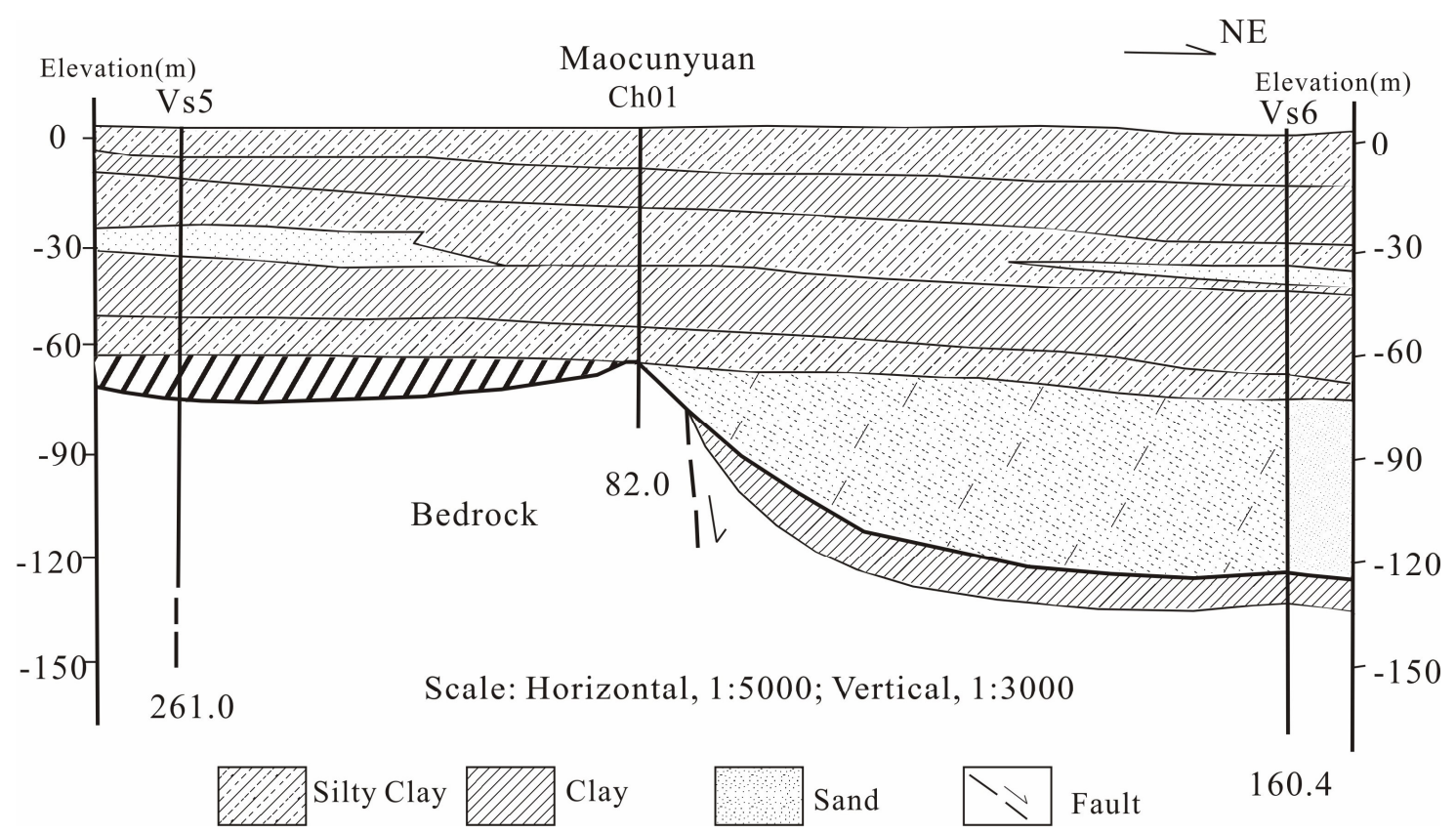

Fig. 5 Quaternary soil profile at Maocunyuan 


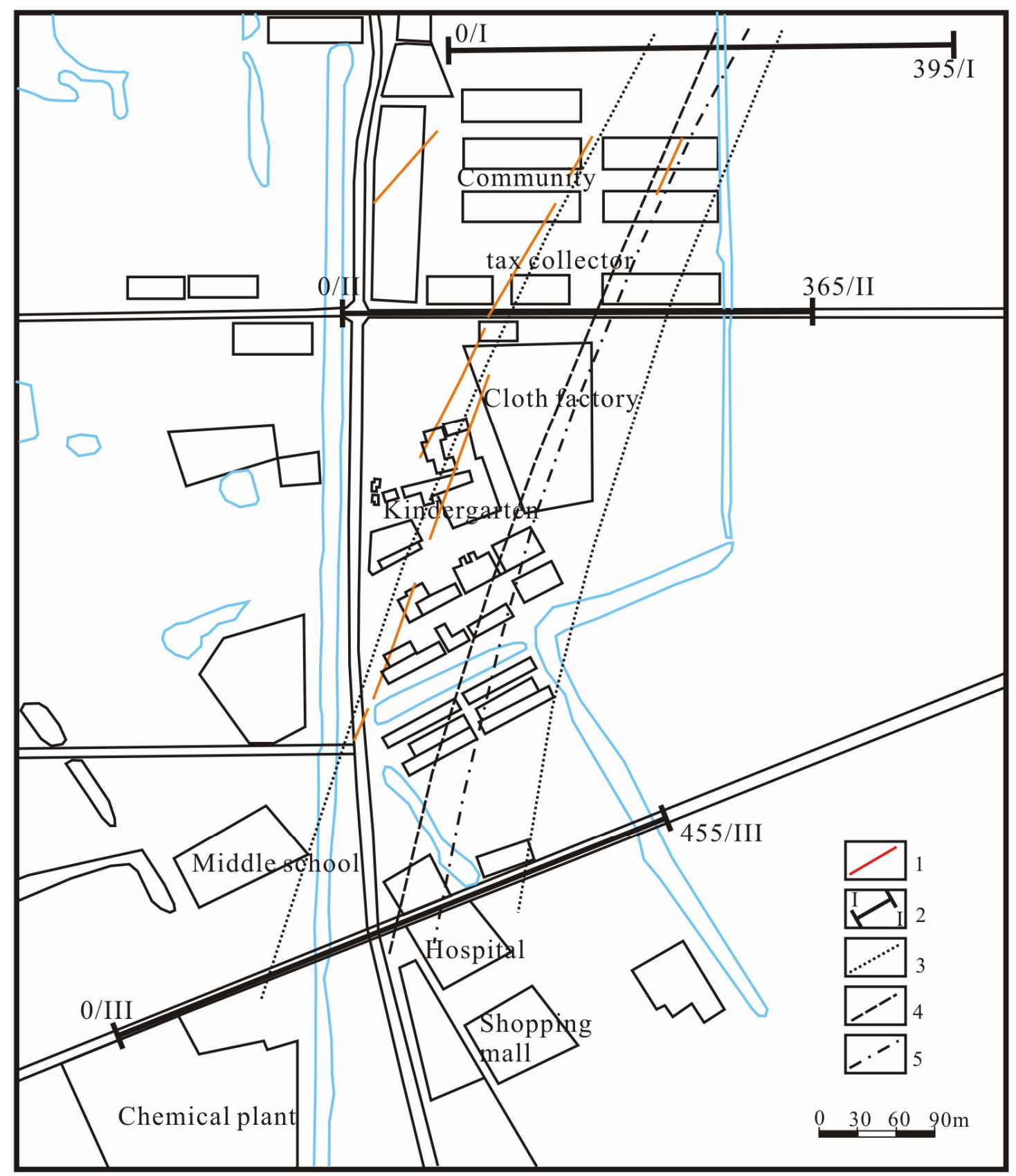

1, earth fissures; 2 , seismic reflection line; 3 , steep edge of bedrock hill; 4 , center line of the bedrock hill; 5 , top line of the bedrock hill

Fig. 6 Distribution of earth fissures at Hetang 


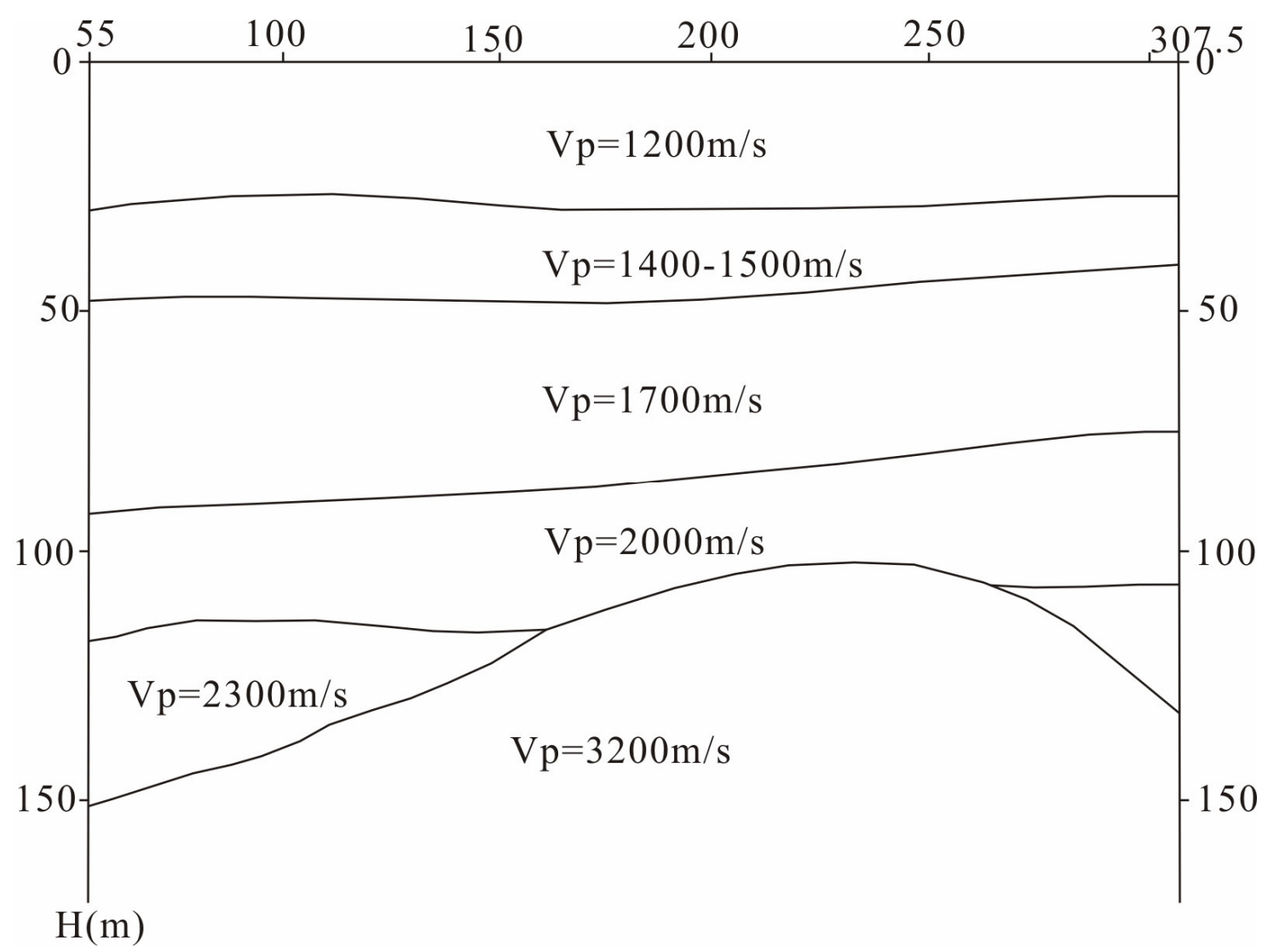

Fig. 7 Bedrock topography determined by shallow seismic reflection at Hetang

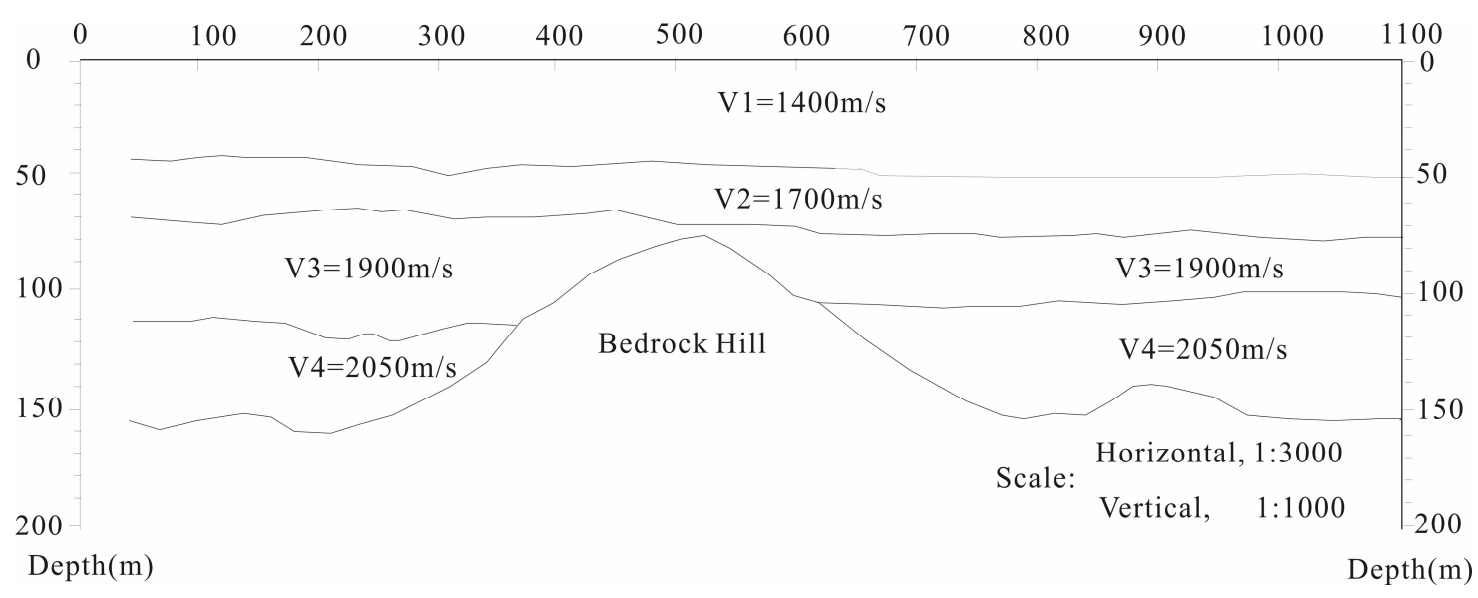

Fig. 8 Bedrock topography determined by shallow seismic reflection at Changjing Town 


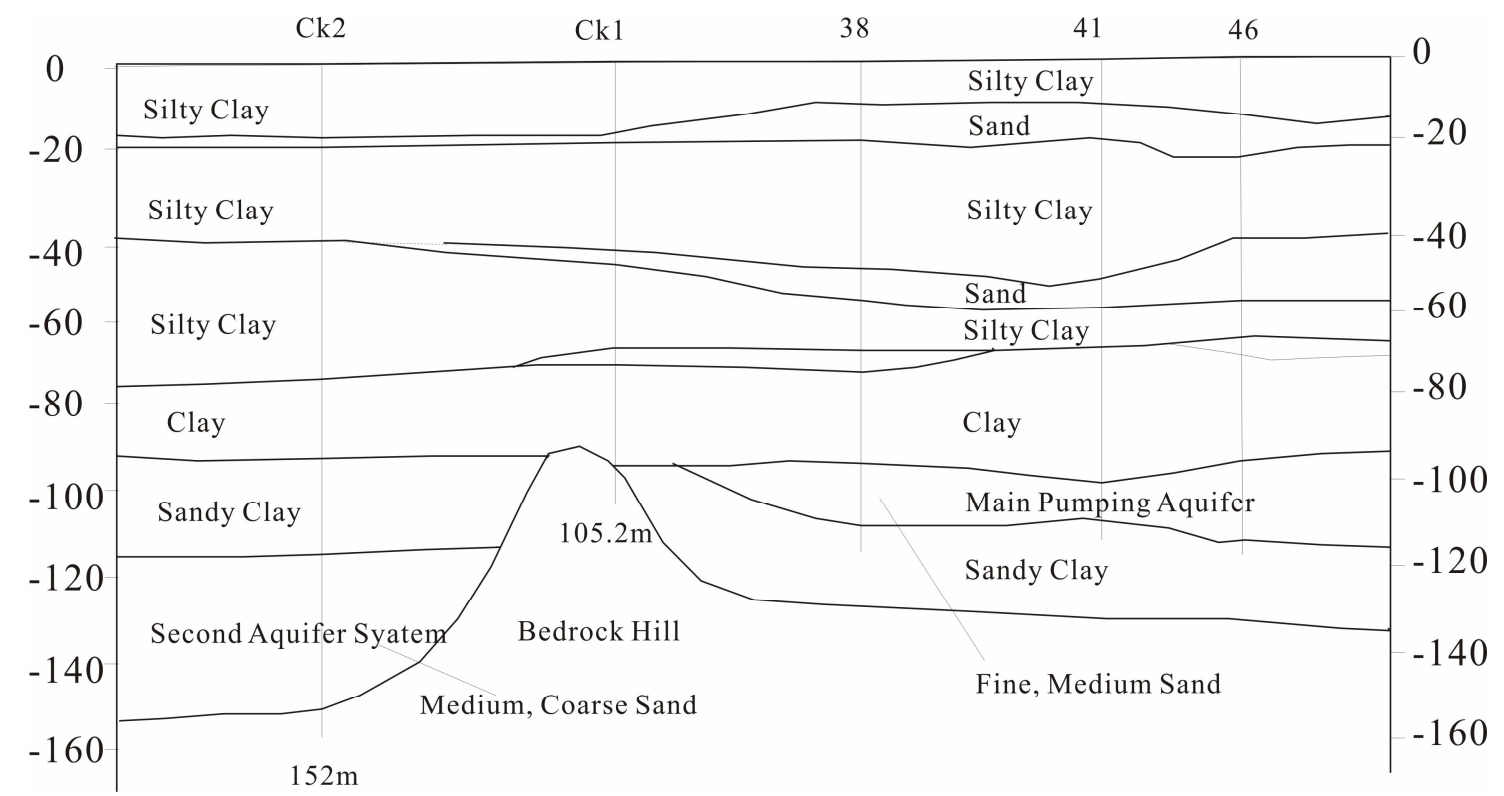

Fig. 9 Quaternary soil profile at Changjing Town 